\title{
COMPARATIVE ANALYSIS OF TRANSPORT ORGANIZATION AND FUNCTIONING OF WATER TRAMS IN GDAŃSK, BYDGOSZCZ AND KRAKÓW
}

\author{
Emilia Miszewska-Urbańska' ${ }^{1}$ Magdalena Apollo \\ 1 Faculty of Civil and Environmental Engineering, Gdańsk University of Technology, Narutowicza 11/12, 80-233 \\ Gdańsk, Poland, e-mail: emilia.miszewska-urbanska@wilis.pg.gda.pl, magdalena.apollo@wilis.pg.gda.pl
}

Received: 2015.12.15

Accepted: 2016.02.01

Published: 2016.03.01

\begin{abstract}
The subject of this work is to identify and juxtapose solutions implemented in transport provided by water trams for the following cities: Gdańsk, Bydgoszcz and Kraków. As a result of the conducted analysis of transport factors, the degree of conformity of project objectives to the actual role of the water tram has been determined. It was found that the Kraków Water Tram (also known as Cracow Water Tram) is characterized by the greatest degree of conformity with project objectives. The solutions adopted in the project can be used to develop organizational and functional standards for this type of transport in Poland, since the lack of system solutions and little experience in implementation of water trams resulted in different organizational and technical approaches in their functioning.
\end{abstract}

Keywords: water tram, percentage of compliance, municipal transport services, sightseeing transport, fleet.

\section{INTRODUCTION}

In the past, inland waterways played an important role not only in the transport of goods, but also as a means of people carriage. The development of rail and road transport, a dense network of roads, increase of speed and availability of other means of transport are the reasons that led to limiting the importance of shipping in the transport of people [1]. Decrease in the importance of transport of goods and raw materials by waterways also caused a strong urban transformation of city centers situated over the water. Relatively recently, Polish cities began to appreciate their locations on waterways and to turn towards the water. Sites of former industrial ports and docks located in city centers have begun to transform into attractive residential areas, cultural and leisure facilities. Strong expansion of water tourism as reflected in building or modernizing of marinas for sailing boats, motor boats, scooters or recreational vessels is noticeable [2].

In addition to cruise ships and hotel-type vessels, newly discovered fleet in Poland are water trams [2] This happened thanks to international grants, especially EU funds allocated to tourism, including water tourism and revitalization of degraded areas which, until recently, were urban areas located on the water.

Lack of system solutions and little experience in the implementation of transport trams in Poland resulted in different organizational and technical approaches in their functioning.

\section{THE UE FUNDS - A CHANCE FOR THE DEVELOMENT OF PASSENGER SHIPPING IN POLAND}

Since $1^{\text {st }}$ May 2004, Poland has been a full member of the European Union, so it participated in the negotiations of the EU budget for the years 2007-2013. At that time our country was allocated Structural Funds of 67.3 billion euro. Polish basic document defining the priorities and delivery system of structural funds for the period 2007-2013 is the National Cohesion Strategy (National Strategic Reference Framework). 
The strategic objective of the National Cohesion Strategy is to create conditions for increasing the competitiveness of the Polish economy based on knowledge and entrepreneurship, ensuring employment growth and an increase of the level of economic, social and territorial coherency [3].

Thanks to EU funds such projects like "The revival of waterways in Gdańsk" (Program ożywienia dróg wodnych w Gdańsku), "Inland navigation tourist trail on the Vistula River in Kraków" (Turystyczny szlak żeglugi śródlądowej na rzece Wiśle w Krakowie) or "Revitalization of boulevards and quays of the Brda river, approx. 4 $\mathrm{km}$, construction of water trams stops" (Rewitalizacja bulwarów i nabrzeży Brdy na odcinku ok. 4 km, budowa przystanków Tramwaju Wodnego) could be realized. They resulted in new waterways, tourist infrastructure in a form of stops, the marinas and waterside areas located in urban centers were revitalized and they became important visiting cards of the cities. Maintaining the EU funds is equally difficult or even more difficult than obtaining them. Decisions made about the functioning of the shelf life of the project are stored in a feasibility study for a long time before the start of the project. That is why it is so important that beneficiaries to make decisions consciously and thoughtfully, they knew how the project is to operate to meet the indicators affecting the maintenance grants and to achieve the intended effects stipulated in the project.

\section{PROGRAM OF REVIVAL OF WATERWAYS IN GDAŃSK}

Thanks to European Funds, the beneficiary i.e. the City of Gdańsk, with its partner the Historical Museum of the City of Gdańsk realized a project entitled: "The revival of waterways in Gdańsk" (PODWwG) under the Operational Program: Innovative Economy 2007-2013, Priority 6. "Polish economy on the international market", Measure 6.4. "Investment in tourism products of supra-regional importance". The value of the project amounted to 37849 101,00 PLN, 17074 128.00 PLN of this amount was subsidized, including the contribution from the European Union: 1451300880 PLN [4].

The aim of the project was to create regional products of supra-regional importance, including:

- opportunity to explore the city of Gdańsk by waterways,
- rest and recreation for whole families the water,

- security maintaining on the waterway and its surroundings [5].

Thus a product composed of two elements came to life:

- infrastructure i.e. 3 marinas and 10 water tram stops,

- two lines of water trams of a total length of 45 $\mathrm{km}[6]$.

Location of the infrastructure -3 marinas and 10 water tram stops, as shown in Figure 1 [6]. As of 2015 additional, $11^{\text {th }}$ stop on the Sobieszewo Island was opened.

\section{INLAND NAVIGATION TOURIST TRAIL ON THE VISTULA RIVER IN KRAKÓW}

The project was to create a new tourism product in the City of Kraków - an inland waterway route on the Vistula River. The project included:

- development of inland waterway route in Krakow,

- construction of the infrastructure necessary for the establishment and smooth functioning of the navigation,

- marking the inland route, promotion of the tourism product, promotion of the project.

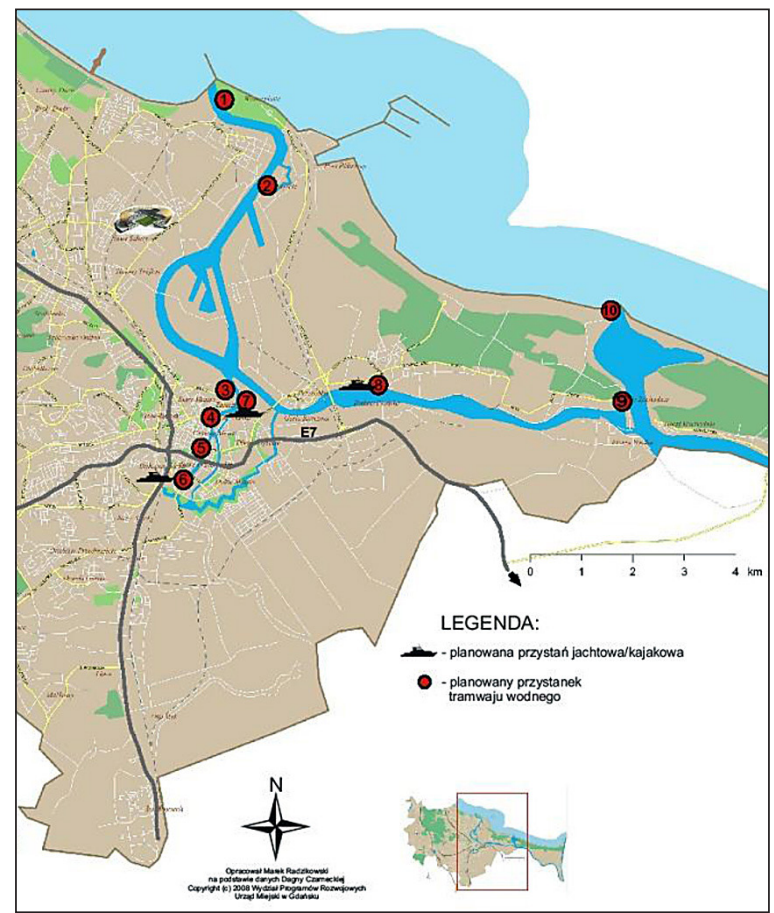

Fig. 1. Deployment of the PODWwG infrastructure [4] 
The task of creating an inland waterway transport in Kraków included measures to determine the course of this route and the appointment of landing sites and moorings in locations that maximize user comfort trail and location of tourist attractions on the banks of the Vistula. The result of the project is $10 \mathrm{~km}$ inland route on the Vistula River. Within the project, infrastructure was developed to operate the inland waterway route in a form of 8-passenger traffic tourist stops on the Vistula River, located on the part of the river Monastery in Tyniec to Kotlarski Bridge in Kraków and 10 moorings located on the Vistula Boulevards [7]. The locations of water trams stops in Kraków on the Vistula River is presented in Figure 2.

The city of Krakow has obtained funds from the European Regional Development Fund under the Malopolska Regional Operational Programme for 2007-2013, priority 3 - Tourism and culture industry, Measure 3.1 - Development of tourism infrastructure, Scheme C - Development of tourist offers products in the region. The value of the project was: 2930 196,37PLN of which a grant: 1 801350.23 PLN, Krakow city's own contribution amounted to 1128846.14 PLN. Implementation period: $31.12 .2008-31.12 .2011$ [7].

\section{BYDGOSZCZ WATERWAY SYSTEM}

The history of the water trams in Bydgoszcz is different from the ones in Gdansk or Krakow and dates back to 1933 when the first regular line water trams on Brda River was launched. Rub by a private owner (Raffke) they operated on the route from the marina at Marcinkowski Street to the "Riviera" pool at Nadrzeczna Street.
Water trams in their present form were created in 2004 on the initiative of the City of City of Bydgoszcz and the University of Economy in Bydgoszcz regular cruises along The Brda River started with the plan of treatment of water trams as a regular means of transport. The first inaugural cruise of Bydgoszcz Water Tram was on $9^{\text {th }}$ October 2004 at 11:00 a.m. [8]. Initially, the water tram route was from Rybi Rynek (Fish Market) to Tesco, and in 2005 two new stops: Astoria and WSG were added.

Bydgoszcz Floodway System, makes that, under these grants, marinas and piers were renovated and water tram stops were built. Of the thirteen projects funded, among others, by the European Union on the Bydgoszcz Floodway two projects include the construction of stops [9].

The first project was financed from the Community Initiative Fund Interreg III, implemented in 2005-2007 under the name "Project the use of inland waterways Vistula, Brda and Bydgoszcz Canal for regional development, including concept of building marinas, water tram stops and the boulevards, embankments, footbridges and park adjacent areas "[10]. The project cost amounted to 0.27 million PLN with grant aid program of 50.7 thousand. $€$.

The second project entitled: "Revitalization of boulevards and quays on the Brda River section approx. $4 \mathrm{~km}$ and construction of water tram stops" [11] was carried out by the Regional Operational Programme Kujawsko-Pomorskie for 2007-2013, its implementation was in the years 2011-2014, total cost amounted to 24.7 million PLN with funding received of 11.43 million PLN.

The result of these complex measures is the creation of 3 lines and 11 water trams stops in Bydgoszcz presented in Figure 3.

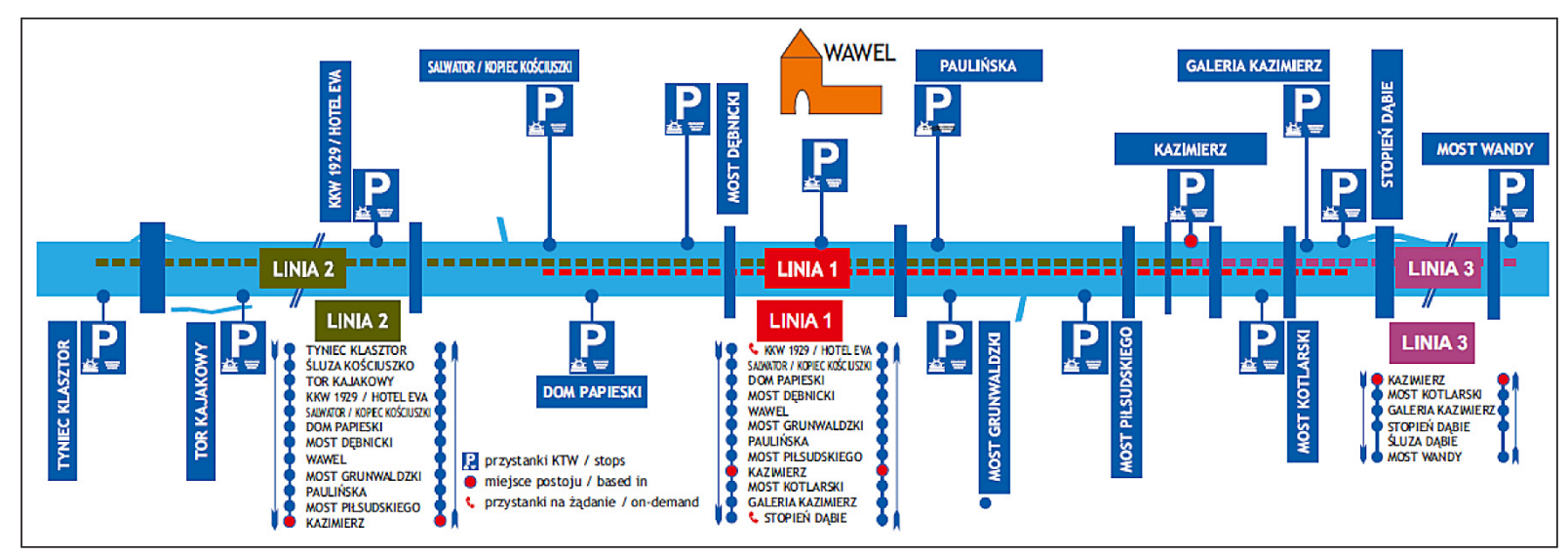

Fig. 2. Distribution of water stops developed as a part of the tourist trail inland navigation on the Vistula River in Kraków [7] 


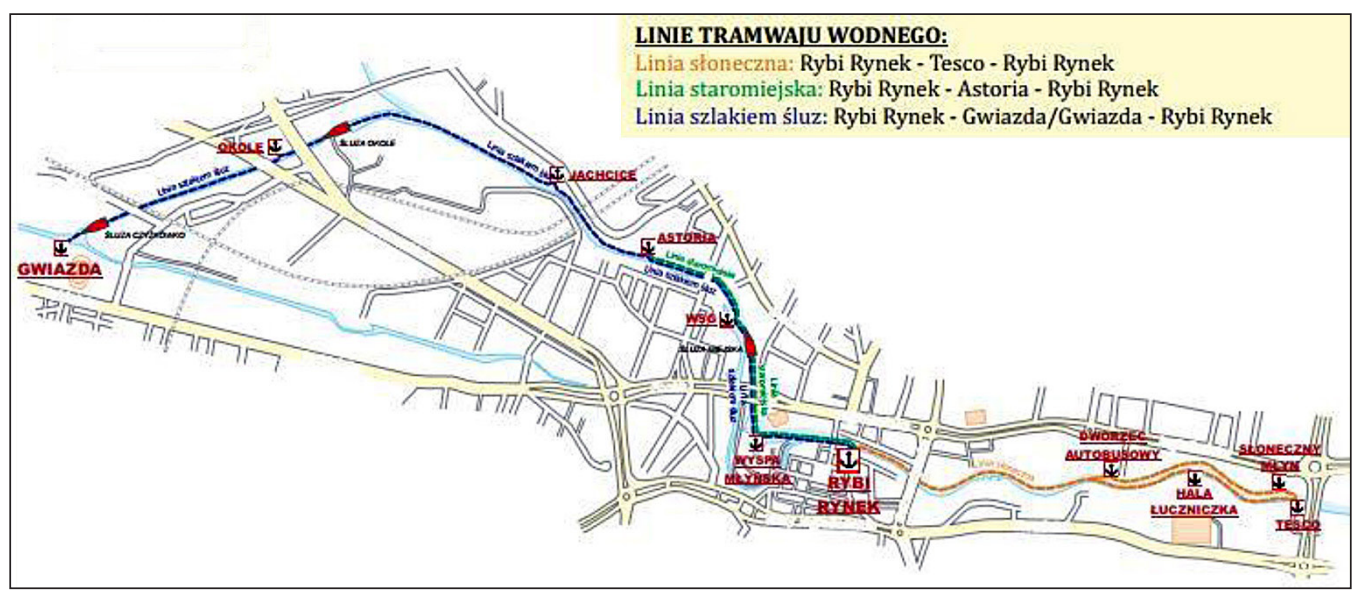

Fig. 3. Water tram line diagram in Bydgoszcz, along with stops [12]

\section{ORGANIZATIONAL SOLUTION IN WATER TRAMS TRANSPORT}

The cities that decided to develop water trams lines adopted different strategy works. This is due to the feasibility study, assumptions made in the design and functions, which is to act as a water trams port infrastructure, resources and its technical status, level of financial resources and sources of grants which were allocated for this purpose. An interesting fact is that in all cities allocated funds for infrastructure and ports on the navigable trails but none of the projects expected the acquisition or construction of vessels.

In Gdańsk, the infrastructure created under the project - harbors and stops - is managed by the Municipal Sports and Recreation Centre in Gdańsk (MOSiR). In the framework of public procurement procedures and on the basis of existing legislation an operator was chosen, which, in its duties, has to take care of port infrastructure and make it available for water trams service. Municipal Transport Management Board is responsible for organization of transport and emergence of the carrier. Transport Authority (ZTM) in Gdańsk has existed since 2005. Its establishment resulted from the need to separate the functions of organization and control of transport from the current exploitation activities, along the lines of the solutions implemented earlier in Western Europe and some Polish cities. City authorities' aim was to create an institution that will analyze both the needs of residents as well as driver costs and rationalize them in terms of budgetary possibilities of the City [13].

ZTM, within its competence, in accordance with the requirements of the Act of 16 December 2010 of the public transport (Journal of laws 2011 no. 5 item 13) and the provisions of the grant agreement, conducted proceedings as a result of which the carrier - firm Żegluga Gdańska Sp. z o.o., was chosen as a carrier of water trams lines. The lines are supported by two passenger ships SONICA and SONICA I, whose technical parameters are determined by navigation conditions on the Old Motława Rever, section of the Green Bridge at Stągiewna Street to the Pod Zrębem/ Zabi Kruk Street through clearances under bridges Zielony, Krowi, Podmiejski and Toruński [14].

In Kraków, the issue of infrastructure management was not distinguished from transport organization, which is run solely by the Board of Sports Infrastructure in Cracow (ZIS). ZIS is a municipal budget unit within the meaning of the Public Finance Act to the extent not covered by the functions of other organizational units of the Municipality. The main areas of its activity is sports and recreation events, especially organizing and administering sports facilities [15]. ZIS is equivalent to MOSiR in Gdańsk. As a result of tender the Kraków Club Water WIR was chosen as an operator which is responsible for implementation of transport trams and stops, for maintaining the water and stops in good condition and purity.

In Bydgoszcz the water tram was initiated by the City Council and the University of Economy and an institution called Municipal Roads and Public Transport (ZDMiKP) which is responsible for transport and infrastructure. ZDMiKP, as an organizational unit of the municipality of Bydgoszcz, was established on $1^{\text {st }}$ March 1994 on the basis of a resolution of the City Council of Bydgoszcz of 17.02.1994. The main objective of the establishment of ZDMiKP was to concentrate, in a single decision-making and realization 
center, total inextricably linked, each other, tasks of the city, under the provisions of the Law on Local Self-Government of 1990 relating to: the construction and maintenance of roads, traffic management and communications infrastructure, organization and management of local public transport. The combination of modern concepts of management of communication and roads is the best solution for planning and implementation of activities for sustainable development of a coherent transport system of the city [16].

\section{FLEET AS A PART OF THE INLAND WATERWAY TRANSPORT SYSTEM}

Proper coordination of project activities is aimed at achieving the intended results and indicators. It is important that each coordinator understands the founding of the project at every stage of its implementation. Under the projects presented in the article, beneficiaries assumed the development of inland waterway transport system. The fleet is one of the three main elements of this system, the other two elements are: waterways and port infrastructure. The term "fleet" should be understood as all water vehicles and vessels, necessary to meet specific transport tasks. Depending on the purpose and role in the implementation of transport tasks, in the literature you can find different criteria for the division of a fleet $[17,18]$. The division, in which the main criterion is the role in the task of transport is shown in Figure 4 [1].

Passengers fleet can be divided into:

- hotel-type vessels of various standards, enabling a group of people spending holidays, moving on the waterways of Poland and Europe,

- cruise ships, allowing to organize day trips, often with restaurants, with the possibility to organize events, also at night,

- water trams, fulfilling the role of public transport, as well as places for organization of several hours' sightseeing tours allowing to visit specific city sides upon the river [1].

\section{SUMMARY OF IMPLEMENTED SOLUTIONS IN WATER TRAMS TRANSPORT}

Depending on the role to be performed by water trams and taking into account the specificities

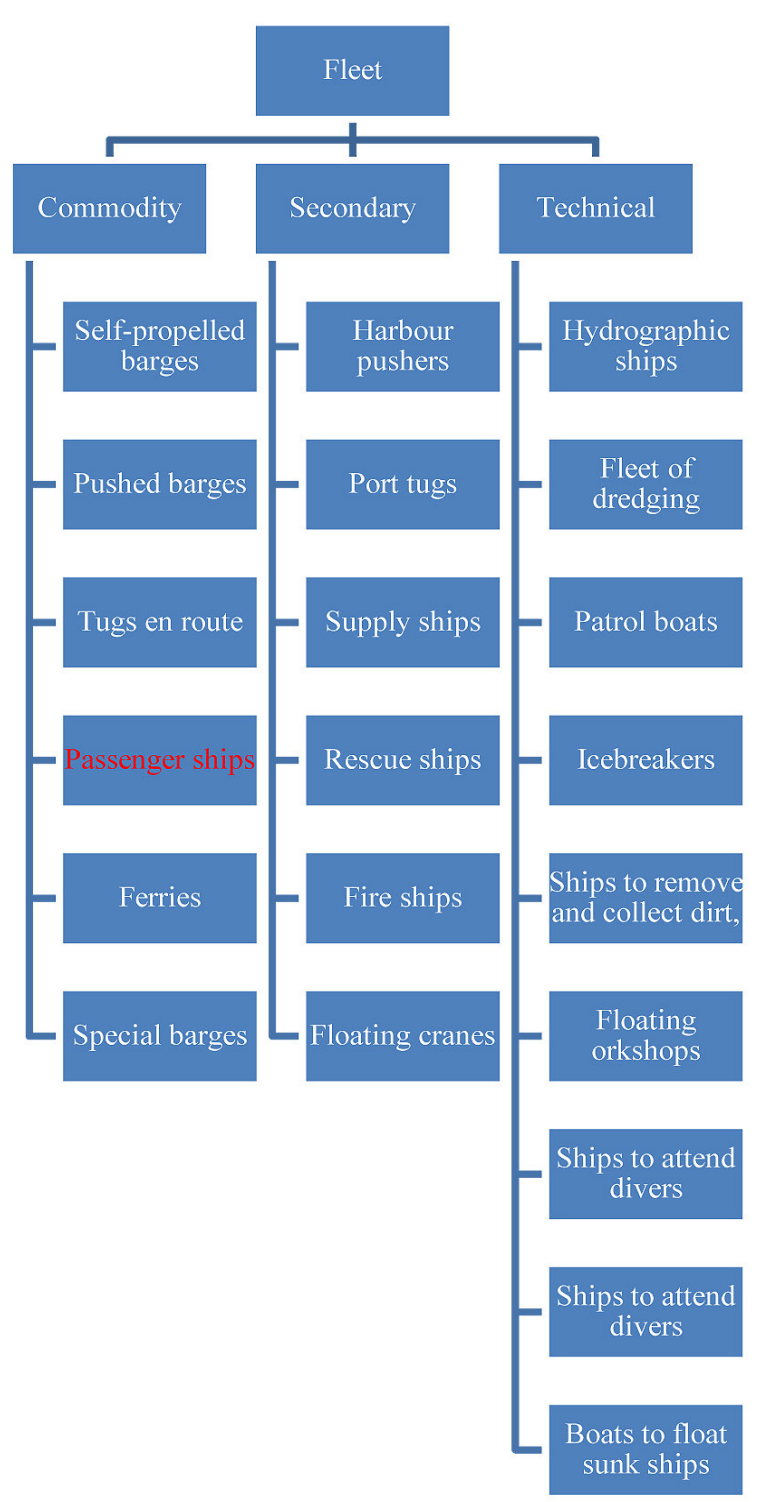

Fig. 4. The basic division of inland waterway fleet [1]

of this means of transport it was necessary to create solutions for:

- distribution, kind, pricing, discounts and ticket inspection,

- aspects connected with operating the lines,

- accessibility for groups and additional attractions.

In Poland, water trams transport is only gaining in popularity so there are only few possibilities to draw knowledge and experience for specific solutions. Cities, creating the projects, drew their experience from abroad, which cannot be always directly translated into Polish conditions. According to the authors, the most important factors of transport were identified and indicated how they present themselves in public transport functional solutions and as a tourist. Then the solu- 
Table 1. Summary information on vessels used as a water trams in Poland [19]

\begin{tabular}{|c|c|c|c|}
\hline Specification & Gdańsk & Bydgoszcz & Kraków \\
\hline Name of the vessel & $\begin{array}{l}\text { Sonica } \\
\text { Sonica I }\end{array}$ & $\begin{array}{l}\mathrm{m} / \mathrm{s} \text { Bydgoszcz, } \\
\text { Słonecznik } \\
\text { Słonecznik II }\end{array}$ & no information \\
\hline Type of the vessel & $\begin{array}{l}\text { Sonica, Sonica I - for transport } \\
\text { of people }\end{array}$ & $\begin{array}{l}\mathrm{m} / \mathrm{s} \text { Bydgoszcz - for transport of } \\
\text { people or as a pusher } \\
\text { Słonecznik and Słonecznik II - } \\
\text { solar passenger vessels }\end{array}$ & $\begin{array}{l}2 \text { passenger catamarans } \\
\text { HM-150 - a tugboat } \\
\text { converted into a passenger } \\
\text { vessel }\end{array}$ \\
\hline Technical data & $\begin{array}{l}\text { Sonica: } \\
\text { - total length }-20.80 \mathrm{~m} \\
\text { - total width }-5.56 \mathrm{~m} \\
\text { - draught }-0.60 \mathrm{~m} \\
\text { - engine: one diesel engine, } \\
\text { type JAMZ-238G, power: } \\
132 \mathrm{~kW} \text {, } \\
\text { - drive: hydrojet; } \\
\text { Sonica I: } \\
\text { - total length }-20.54 \mathrm{~m} \\
\text { - total width }-5.50 \mathrm{~m} \\
\text { - draught - } 0.61 \mathrm{~m} \\
\text { - engine: one diesel engine, } \\
\text { type JAMZ-238G, power: } \\
\text { 132 kW, } \\
\text { - drive: hydrojet }\end{array}$ & $\begin{array}{l}\text { m/s Bydgoszcz: } \\
\text { - total length: } 14.85 \mathrm{~m} \text {, } \\
\text { - total width: } 3.88 \mathrm{~m} \text {, } \\
\text { - max. draught: } 1.13 \mathrm{~m}, \\
\text { - operating speed: } 10 \mathrm{~km} / \mathrm{h}, \\
\text { - engine: "Delfin" type, } 1654 \mathrm{HP} \text {; } \\
\text { Slonecznik and Słonecznik I: } \\
\text { - total length: } 13.46 \mathrm{~m} \text {, } \\
\text { - total width: } 3.07 \mathrm{~m} \text {, } \\
\text { - draught: } 0.36 \mathrm{~m} \text {. }\end{array}$ & $\begin{array}{l}\text { Catamaran: } \\
\text { - length: } 7 \mathrm{~m} \text {, } \\
\text { - width: } 3.5 \mathrm{~m} \text {, } \\
\text { - engine: outboard. } \\
\text { HM-150 } \\
\text { no data }\end{array}$ \\
\hline Number of passengers & 40 & $\begin{array}{l}\mathrm{m} / \mathrm{s} \text { Bydgoszcz }-24, \\
\text { Słonecznik and Slonecznik II }-28\end{array}$ & $\begin{array}{l}\text { Catamaran - } 12 \\
\text { HM-150 - ? }\end{array}$ \\
\hline Number of crew & Minimum 2 people & $\begin{array}{l}\mathrm{m} / \mathrm{s} \text { Bydgoszcz }-3 \\
\text { Słonecznik and Słonecznik II - } 2\end{array}$ & $\begin{array}{l}\text { Catamaran - } 1 \\
\text { HM-150 - ? }\end{array}$ \\
\hline Toilet & Yes & Yes - Słonecznik & No \\
\hline Shelter on water conditions & Yes & $\begin{array}{l}\text { No - Słonecznik } \\
\text { Yes - m/s Bydgoszcz }\end{array}$ & Yes \\
\hline Sheltered sightseeing place & Yes & $\begin{array}{l}\text { No - Słonecznik } \\
\text { Yes - m/s Bydgoszcz }\end{array}$ & Yes \\
\hline
\end{tabular}

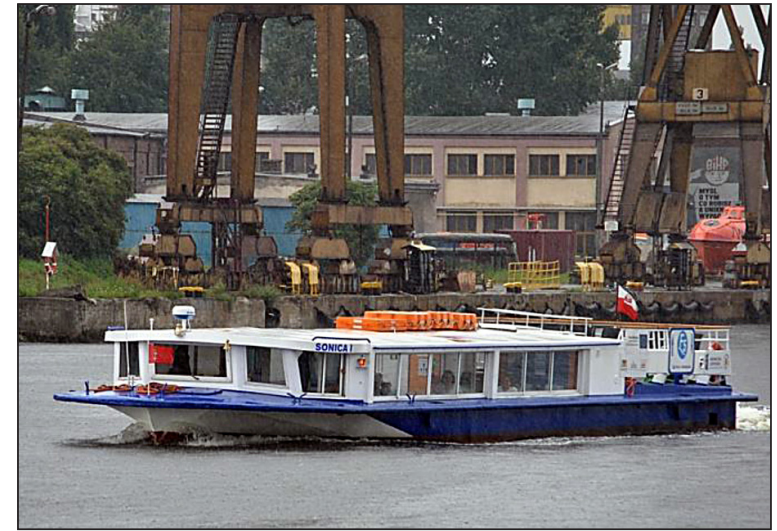

Fig. 5. Sonic I during a course on line F5 [14]

tions adopted in Bydgoszcz, Gdansk and Krakow were placed in the table in condemning whether the factor is closer to the solution adopted in the transport and tourist transport. The data from the analysis are summarized in Table 2.

Summary of implemented solutions in the transport by water trams organizes information and gives basis for comparison in which the project of water trams role is closest to the original assump-

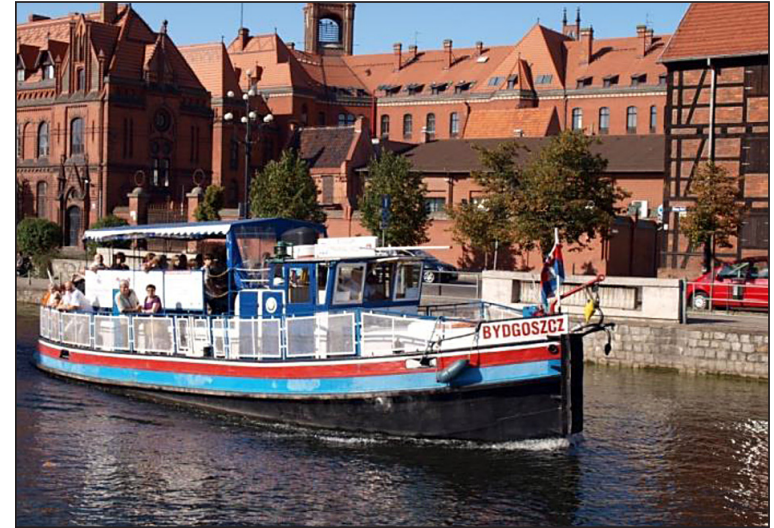

Fig. 6. Historic motor powered ship m/s Bydgoszcz [20]

tions and expectations. Accuracy of the transport medium and implemented solutions as indicated in Table 2 is indicated in Table 3 by "+". Assuming that the compatibility of the factors considered with complete transport solutions existing in various cities are $100 \%$, compatibility factors that have a particular project originally specified function were calculated. A full summary and the percentage of compliance is shown in Table 3. 


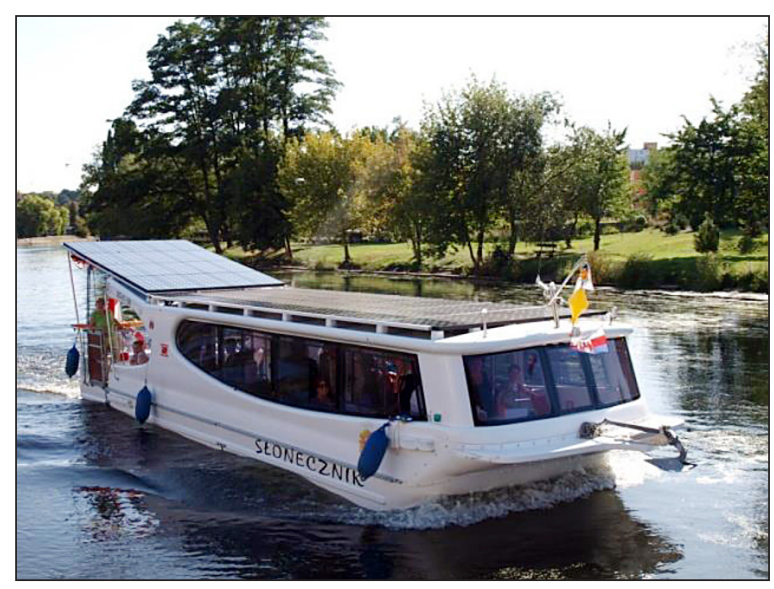

Fig. 7. Two solar-powered ships "Słonecznik" and "Słonecznik II" [21]

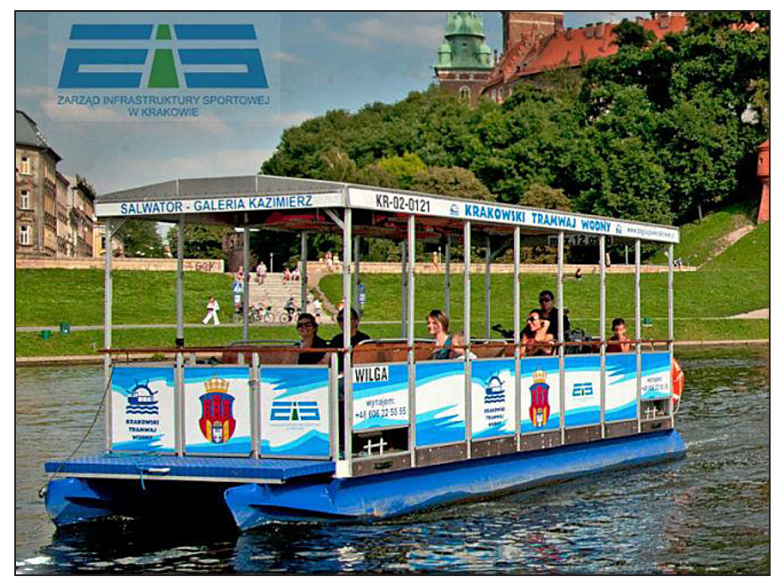

Fig. 8. Krakow water tram [22]

Table 2. Summary of implemented solutions in water trams transport [19]

\begin{tabular}{|c|c|c|c|c|c|}
\hline Transport agent & $\begin{array}{c}\text { Municipal transport } \\
\text { services }\end{array}$ & $\begin{array}{l}\text { Sightseeing } \\
\text { transport }\end{array}$ & Gdansk & Bydgoszcz & Krakow \\
\hline \multicolumn{6}{|c|}{ Tickets } \\
\hline $\begin{array}{l}\text { Distribution of } \\
\text { tickets }\end{array}$ & $\begin{array}{l}\text { Common, easily } \\
\text { accessible }\end{array}$ & $\begin{array}{l}\text { Tickets available } \\
\text { from a carrier before } \\
\text { entering the unit }\end{array}$ & $\begin{array}{l}\text { Tickets available } \\
\text { from a carrier before } \\
\text { entering the unit }\end{array}$ & $\begin{array}{l}\text { Tickets available } \\
\text { from a carrier before } \\
\text { entering the unit }\end{array}$ & $\begin{array}{l}\text { Tickets available } \\
\text { from a carrier before } \\
\text { entering the unit }\end{array}$ \\
\hline Kinds of tickets & Big choice of tickets & $\begin{array}{l}\text { One kinds of tickets, } \\
\text { one-way tickets }\end{array}$ & $\begin{array}{l}\text { One kinds of tickets, } \\
\text { one-way tickets }\end{array}$ & $\begin{array}{l}\text { One kinds of tickets, } \\
\text { one-way tickets }\end{array}$ & $\begin{array}{l}\text { One kinds of tickets, } \\
\text { one-way tickets }\end{array}$ \\
\hline Price list & $\begin{array}{l}\text { Equal for the whole } \\
\text { system }\end{array}$ & $\begin{array}{l}\text { Fixed only for the } \\
\text { water tram, not } \\
\text { compatible with the } \\
\text { municipal system }\end{array}$ & $\begin{array}{l}\text { Fixed only for the } \\
\text { water tram, not } \\
\text { compatible with the } \\
\text { municipal system }\end{array}$ & $\begin{array}{l}\text { Fixed only for the } \\
\text { water tram, not } \\
\text { compatible with the } \\
\text { municipal system }\end{array}$ & $\begin{array}{l}\text { Fixed only for the } \\
\text { water tram, not } \\
\text { compatible with the } \\
\text { municipal system }\end{array}$ \\
\hline $\begin{array}{l}\text { Discounts and } \\
\text { reductions }\end{array}$ & $\begin{array}{l}\text { According to regu- } \\
\text { lations }\end{array}$ & $\begin{array}{l}\text { At the discretion of } \\
\text { the carrier, often } \\
\text { only for children or } \\
\text { groups }\end{array}$ & $\begin{array}{l}\text { As for municipal } \\
\text { transport }\end{array}$ & $\begin{array}{l}\text { As for municipal } \\
\text { transport }\end{array}$ & Only for children \\
\hline Booking & $\begin{array}{l}\text { Not possibility of } \\
\text { booking }\end{array}$ & $\begin{array}{l}\text { It is a possibility to } \\
\text { book a travel }\end{array}$ & $\begin{array}{l}\text { Not possibility of } \\
\text { booking }\end{array}$ & $\begin{array}{l}\text { It is a possibility to } \\
\text { book for groups }\end{array}$ & $\begin{array}{l}\text { Not possibility of } \\
\text { booking }\end{array}$ \\
\hline \multicolumn{6}{|c|}{ Line } \\
\hline Number of lines & Many lines & Few & 2 & 3 & 3 \\
\hline Location of stops & $\begin{array}{l}\text { According to the } \\
\text { citizens' needs }\end{array}$ & $\begin{array}{l}\text { Close to tourist } \\
\text { attractions }\end{array}$ & $\begin{array}{l}\text { Close to tourist } \\
\text { attractions }\end{array}$ & $\begin{array}{l}\text { Close to tourist } \\
\text { attractions }\end{array}$ & $\begin{array}{l}\text { Close to tourist } \\
\text { attractions }\end{array}$ \\
\hline Service frequency & $\begin{array}{l}\text { According to the } \\
\text { citizens' needs and } \\
\text { financial means }\end{array}$ & $\begin{array}{l}\text { According to popu- } \\
\text { larity }\end{array}$ & 3 cruises a day & 12 cruises a day & $\begin{array}{l}\text { Depending on the } \\
\text { line - up to } 4 \text { cruises } \\
\text { a day }\end{array}$ \\
\hline $\begin{array}{l}\text { Seasonality, hourly } \\
\text { interval }\end{array}$ & $\begin{array}{l}\text { Yearly round-the- } \\
\text {-clock }\end{array}$ & $\begin{array}{l}\text { Seasonal, depend- } \\
\text { ing on tourists' } \\
\text { needs }\end{array}$ & Seasonal, daylight & Seasonal, daylight & Seasonal, daylight \\
\hline \multicolumn{6}{|c|}{ Others } \\
\hline $\begin{array}{l}\text { Accessibility for } \\
\text { groups }\end{array}$ & $\begin{array}{l}\text { There is a possibility } \\
\text { of taking organized } \\
\text { groups on the prin- } \\
\text { ciples like individual } \\
\text { passengers }\end{array}$ & $\begin{array}{l}\text { Organized groups } \\
\text { are preferred }\end{array}$ & $\begin{array}{l}\text { Limited possibility of } \\
\text { taking an organized } \\
\text { group because } \\
\text { of the number of } \\
\text { places }\end{array}$ & $\begin{array}{l}\text { Limited possibility of } \\
\text { taking an organized } \\
\text { group because } \\
\text { of the number of } \\
\text { places }\end{array}$ & $\begin{array}{l}\text { Limited possibility of } \\
\text { taking an organized } \\
\text { group because } \\
\text { of the number of } \\
\text { places }\end{array}$ \\
\hline $\begin{array}{l}\text { Additional attrac- } \\
\text { tions }\end{array}$ & $\begin{array}{l}\text { There are no addi- } \\
\text { tional attractions on } \\
\text { the unit }\end{array}$ & $\begin{array}{l}\text { Possibility, among } \\
\text { others: the purchase } \\
\text { of food and bever- } \\
\text { ages, live music }\end{array}$ & $\begin{array}{l}\text { No additional attrac- } \\
\text { tions on the board }\end{array}$ & $\begin{array}{l}\text { No additional attrac- } \\
\text { tions on the board }\end{array}$ & $\begin{array}{l}\text { No additional attrac- } \\
\text { tions on the board }\end{array}$ \\
\hline
\end{tabular}


Table 3 Selection of the degree of compliance with established transport agents function [19]

\begin{tabular}{|c|c|c|c|c|c|c|}
\hline \multirow[b]{2}{*}{ Transport agent } & \multicolumn{2}{|c|}{ Gdańsk } & \multicolumn{2}{|c|}{ Bydgoszcz } & \multicolumn{2}{|c|}{ Kraków } \\
\hline & $\begin{array}{c}\text { municipal } \\
\text { transport } \\
\text { services }\end{array}$ & $\begin{array}{l}\text { sightseeing } \\
\text { transport }\end{array}$ & $\begin{array}{c}\text { municipal } \\
\text { transport } \\
\text { services }\end{array}$ & $\begin{array}{l}\text { sightseeing } \\
\text { transport }\end{array}$ & $\begin{array}{l}\text { municipal } \\
\text { transport } \\
\text { services }\end{array}$ & $\begin{array}{l}\text { sightseeing } \\
\text { transport }\end{array}$ \\
\hline Function & & + & + & & & + \\
\hline \multicolumn{7}{|l|}{ Tickets } \\
\hline Distribution of tickets & & + & & + & & + \\
\hline Kinds of tickets & & + & & + & & + \\
\hline Price list & & + & & + & & + \\
\hline Discounts and reductions & + & & + & & & + \\
\hline Booking & + & & $+/-$ & $+/-$ & & + \\
\hline \multicolumn{7}{|l|}{ Line } \\
\hline Number of lines & & + & & + & & + \\
\hline Location of stops & & + & & + & & + \\
\hline Service frequency & & + & + & & & + \\
\hline Seasonality, hourly interval & & + & & + & & + \\
\hline \multicolumn{7}{|l|}{ Others } \\
\hline Accessibility for groups & + & & $+/-$ & $+/-$ & + & \\
\hline Additional attractions & + & & + & & + & \\
\hline Percentage of compliance [\%] & \multicolumn{2}{|c|}{63.64} & \multicolumn{2}{|c|}{36.36} & \multicolumn{2}{|c|}{81.82} \\
\hline
\end{tabular}

\section{CONCLUSIONS}

The decrease in the importance of transport of goods by inland waterways resulted in degradation of not only the importance of this means of transport but also the destruction of the urban areas located by the water in Polish cities. After years, thanks to global trends in urban planning, there is an increase of awareness of the inhabitants and the city authorities and the popularity of water tourism, this trend began to change. The city began to appreciate the waterside areas and navigable routes. An additional element supporting the development of tourism and water routes became the Polish accession to the European Union. This fact allowed to apply for funds for projects related to tourism and revitalization. New insights into the possibilities of using water in urban areas gave little chance to develop a popular means of transport which is a water tram. However, the lack of system solutions and little experience in the implementation of transport trams caused discrepancy in developing solutions to organizational and functional means of transport of this type in Polish cities.

Organizational solutions, although divergent between different cities, including main objectives and targets have been created in a correct way. They assumed the separation of tasks set in the project between municipal units adequately for their competence. In the authors' opinion, the best solution is to transport organization and administration of public transport stops to Public Transport Company (or other equivalent competency unit), which has the biggest experience in this field. The remaining infrastructure in a form of the harbors and marinas must be submitted to the municipal entities involved in the administration of objects related to sports and recreation, irrespective of the question whether the tasks described in the project will be carried out directly by the city or indirectly by an operator selected in tender.

It should be noted that in all analyzed cities, funds received from grants were used to infrastructure and to create navigable routes, but none of the projects expected the acquisition or construction of vessels. It is interesting due to the fact that inland waterway transport is composed of three elements: harbour infrastructure, navigable routes and fleet.

This may result from lack of experience in the organization and functioning of water transport by Polish cities, high cost of maintaining the vessels, crew having to work full-time, high costs of construction or purchase of vessels and provisions of feasibility study. The only ship owner among the three cities examined in the article is Bydgoszcz, which has two vessels. 
Each of the presented water trams has a noticeable problem which is the number of passengers that can be taken onboard. This is more important if the main assumption of the project of water trams was supposed to serve for tourism purposes. At the moment, none of the vessels can be used by a standard group of visitors approx. 50 people. The only vessel that meets the highest expectations in terms of tourism is Gdańsk water tram, which has an outdoor terrace, glassedin cubicle, toilet and can take many passengers. In comparison with the other vessels, the worst is the Kraków Water Tram. In addition to very limited number of passengers (12) an additional drawback is the lack of closed cab that protects passengers from wind and rain.

Identification of the implemented solutions in the water trams transport for Gdańsk, Bydgoszcz and Kraków concerning, among others tickets, lines and availability, and their interplay with the municipal transport and tourism has enabled the consistency of the project objectives for the role of water trams. The higher the percentage of compliance with data transport factors functional solutions adopted in this project the most accurate solutions have been proposed and implemented. As a result of the analysis, it turned out that the project, which showed the greatest degree of compliance solutions to functional roles under the initial assumptions is Kraków Water Tram, the lowest degree of compliance showed Bydgoszcz Water Tram. On this basis, it can be concluded that the solutions implemented in the project in Kraków could become the basis for developing organizational and functional standards in other Polish cities.

\section{REFERENCES}

1. Winter J., Kulczyk J. Śródlądowy transport wodny. Oficyna Wydawnicza Politechniki Wrocławskiej. Wrocław 2003.

2. Miszewska-Urbańska E., Apollo M. Analiza porównawcza funkcjonowania i organizacji przewozów tramwajami wodnymi dla Gdańska, Bydgoszczy i Krakowa. Streszczenie na konferencje INFO-TRANS'2015, niepublik.

3. Agencja J\&J Jowita Zielinkiewicz, Fundusze UE 2007-2013 [access: 28.01.2014] http://www. agencjajj.pl/index.php? $\mathrm{n}=330$

4. Polska Agencja Turystyczna, Lista projektów. [access: 20.01.014], http://www.pot.gov.pl/dzialanie- 6-4-po-ig/lista-projektow/

5. Urząd Miejski w Gdańsku, Program ożywienia dróg wodnych w Gdańsku. [access: 27.01.2014], http://www.gdansk.pl/nasze-miasto,1119.html

6. Miszewska-Urbańska E. Rola nowego tramwaju wodnego w Gdańsku. Czasopismo Logistyka, 3, 2014, 4438-4446.

7. Zarząd Infrastruktury Sportowej w Krakowie, Turystyczny szlak żeglugi śródlądowej w Krakowie. [access: 30.08.2015], http://www.zis.krakow.pl/

8. Towarzystwo Miłośników Miasta Bydgoszczy. Encyklopedia Bydgoszczy, tom 1. Bydgoszcz 2011.

9. Winfield Scott, Bydgoski Węzeł Wodny, [access: 28.08.2015], http://www.info24.org.pl/

10. Wykorzystanie Śródlądowych Dróg Wodnych dla Rozwoju Regionalnego (In Water), [access: 30.07.2015], http://web.archive.org/web/20071111 024542/; http://www.bydgoszcz.pl/binary/In\%20 Water_tcm29-22357.pdf

11. Biuletyn Informacji Publicznej Miasta Bydgoszczy, Uchwały nr XIII/170/11 Rady Miasta Bydgoszczy z dnia 28 czerwca 2011 roku, [access: 15.07.2015], http://bip.um.bydgoszcz.pl/

12. Bydgoski Tramwaj Wodny, Mapa trasy, [access: 18.07.2015], http://tramwajwodny.byd.pl/aktualnosci-z-zdmikp/

13. Zarząd Transportu Miejskiego w Gdańsku, O ZTM, [access: 15.07.2015], http://www.ztm.gda.pl/

14. Zarząd Transportu Miejskiego w Gdańsku, Tramwaj wodny, [dostęp 05.02.2014], http://www.ztm. gda.pl/

15. Zarząd Infrastruktury Sportowej, O nas, [access: 10.08.2015], http://www.zis.krakow.pl/

16. Zarząd Dróg Miejskich i Komunikacji Publicznej, Historia powstania, [access: 10.08.2015], http://zdmikp.bydgoszcz.pl/

17. Główczyński S., Gronowski F., Żegluga Śródlądowa. Ekonomika, eksploatacja, organizacja. WKiŁ, Warszawa 1979.

18. Żylicz A., Statki śródlądowe. Wydawnictwo Morskie, Gdańsk 1979.

19. Miszewska-Urbańska E., Opracowanie własne.

20. Bydgoski Tramwaj Wodny, Galeria, [access: 18.07.2015], http://tramwajwodny.byd.pl/aktualnosci-z-zdmikp/

21. Zarząd Dróg Miejskich i Komunikacji Publicznej, Bydgoski Tramwaj Wodny, [access: 10.08.2015], http://zdmikp.bydgoszcz.pl/

22. Infoship.pl, Kraków: tramwaj wodny wraca w maju, [access: 18.07.2015], http://infoship.pl/krakowtramwaj-wodny-wraca-w-maju_more_72929. html; 